University of Louisville

ThinkIR: The University of Louisville's Institutional Repository

Electronic Theses and Dissertations

1932

\title{
A study of the movements of the heart and their relationship to the filling of the auricles.
}

John H. Rompf

University of Louisville

Follow this and additional works at: https://ir.library.louisville.edu/etd

Part of the Cardiology Commons

\section{Recommended Citation}

Rompf, John H., "A study of the movements of the heart and their relationship to the filling of the auricles." (1932). Electronic Theses and Dissertations. Paper 1883.

https://doi.org/10.18297/etd/1883

This Master's Thesis is brought to you for free and open access by ThinkIR: The University of Louisville's Institutional Repository. It has been accepted for inclusion in Electronic Theses and Dissertations by an authorized administrator of ThinkIR: The University of Louisville's Institutional Repository. This title appears here courtesy of the author, who has retained all other copyrights. For more information, please contact thinkir@louisville.edu. 


\title{
UNIVERSITY OF LOUISVILIE
}

A STUDY OF THE MOVEMENTS OF THE HEART AND THEIR RELATIONSHIF TO THE FITLING OF THE AUfRICLES.

\author{
A Dissertation \\ Submitted to the Faculty \\ Of the Graduate School of the university of Louisville \\ In Partial Fulfillment of the \\ Requirements of the Degree \\ of Master of Science
}

Department of Physiology

By

John H.Rompf 
conprises.

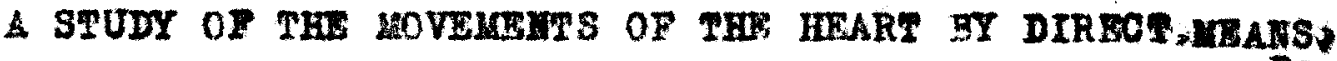

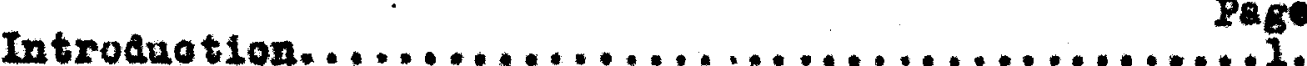

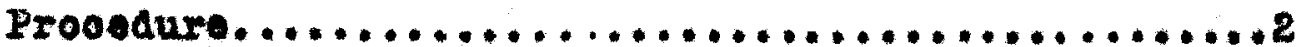

Conslaeration os the funetion of the frenul.1n.....7

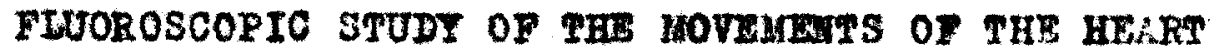

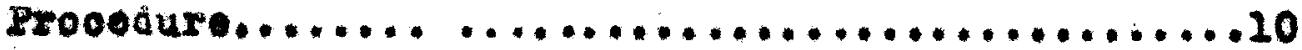

Consideration of the slenifloanot of sluoroseoplo

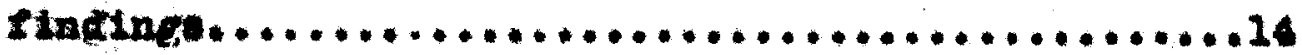

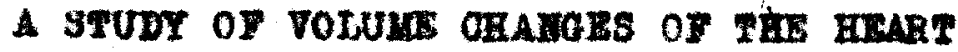

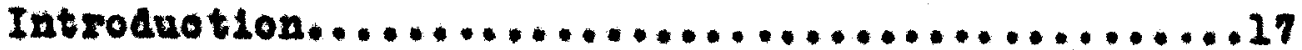

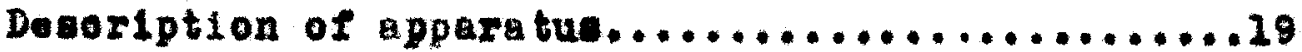

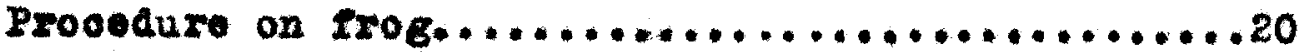

Prooedure on turt10.........................24

Prooedure on dog.............................27

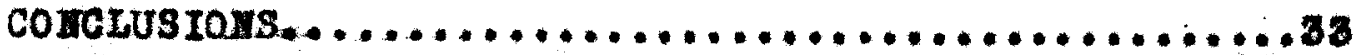

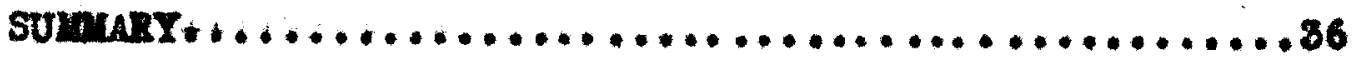

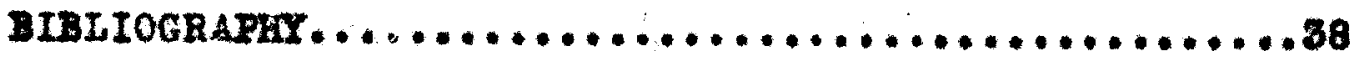


A STUDY OF THE MOVBaETS OF THE HEART AND

THEIF RELATIONSHIP TO THE FILLIKG OF THE AURICLRS.

The movements whioh various perts of the hert undergo aro not easily observable in the intsot animal, and for this reason thelr signifloanoe has not been wholly undoretood. Fhree centuries go Harvey (1) stated that he a lmoet believed that the motion of the heart was to be uncerstood by cod lone. However, ho desoribed it a boooming narrower and longer as it contraote, but other observers have shown that a shortening really occurs.

It 18 easly seen by alreot oberyation of the exposed heart In a living animal, that the systollo shortening of its longltudinal axis oooure not by a lifting of the apox, but by a downward movement of the base. This wes lirst observed by Leonardo ds Vinci $(1452-1629)$, who stated that "if three needles be passed through the ohest wall so that their points 110 , one in the bese, one about the middle of the ventricles, and one in the apex of the ventrioles, esch ventrioulor systole is socompanied by a downward movement of the neecile in the buse of the hext, a sighter downera movement of the oldale needle, and practically no movement at 11 of the needie whioh is thrust into the apex"(2).

Hayoraft (3) in 1892 by the same method abtuined the same results on the heart of the oat and rabbit. W1geere (4) a180 desoribes this downward movement of the base of the heart durine oystolo and attributes the shary fall during ventricular systole or his intra-burloular pressure curves to this cause.

Lew1: (b) desoribes the wovoment of a bull at lodece in the heart of a man. From $x-r a y$ eximination the builet we bellevea 
to 110 in the interventrioular septum. It was nesrer the apex than the base of the heart, and with esoh systole it showed a slight downward worement when rlewed laterally.

If the chest weil of an inted fros 18 carelully observed. a glight pulsation oan be seen ot each hesrt bect, but this olight movemont is by no means comparable to the volume of blood whioh flows from the hoset at each beat. Since the tiseues forming the anterior oheat wall in the frog are thin and easily movable. It seems that the total volume of the heart wat be remining lmost constant auring syetole, or there would be a more marked pulation of the ohest well. In oraer for the totel heart volume to remsin constent during aystole, blood must be filing the aurioles completely during the eame period that the ventriole 18 emptying.

When the heart 18 exposed, movement of the orgtins eurrounding it would be observable at each systole if this were not the oase. Such a movement rould be wating the energy of the hear. However, observation shows thot very ilttle movement of the oreans surrounding the heart really ocours, beonuse the downwerd movement of the furioulo-ventrieular septum at each systole allows the gurlolo to 1111 durl. 6 this perloa. Whe heart 18 thus engbled to expend its enerey in moving blood, instead of we at ing some of it in moving the surrounding orfons.

Prooedure: A direot atudy of the movenents of the herrt of the froc, turtie, and $\mathrm{dog}$ wa made. The movementa wore recorded by meane of leverg of the type shown in Fig. 1 . 


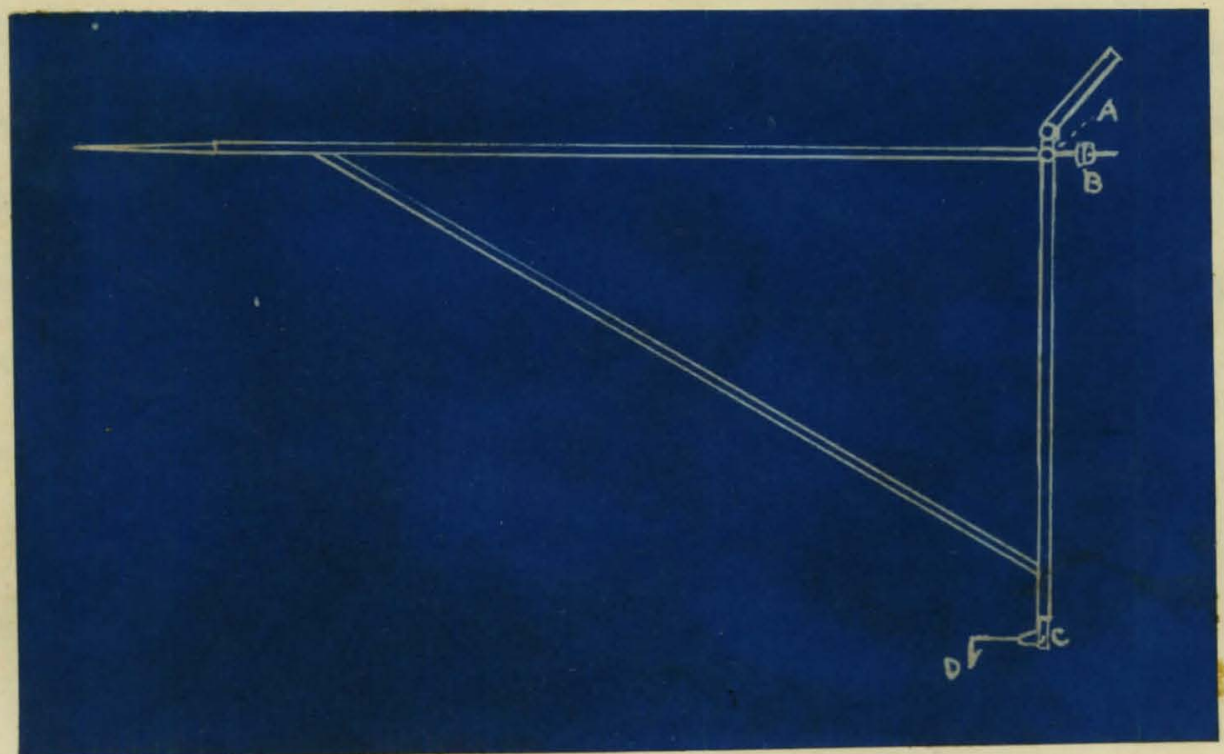

Fig.1. Drawing of lever used to record movements of frog, turtle, and dog heart. Magnifiestion is $2: 1$. A- Pin pivot. B-weight usea for counterbslancing lever. $C$ - hinge used to prevent movements other than toward the head or tall from being recordea. D- barb used to hold wire in heart.

The levers were constructed of thin strips of balsa wood, care being taken to prevent excessive weight. The pin type of pivot was used to minimize friction, and the levers were counterbalanced by sins 11 weights. Attachment to the heart was made by means of a hinged wire arrangement, which allowed only movements toward or away from the head to be recorded. A small metal barb was soldered to the end of the wire so thet it could not slip out of the heart muscle. The writing point on the lever was a thin strip of celluloid. lecordine was done on a kymograph drum covered with cellophene smoked over a kerosene Ilame. The records 
when flxed by paselas through a beth of thinned ahellas and aried. were printed upon elther blueprint paper or photoexaphlo paper. slides for projection purposes were made by putting seotions of the recoras between pleoes of thin 6 lass. viseoher (6) deecribes athod of uaing oellophane for reoording in whioh a compreased ir spray is ueed for black ening and flxing the arums. However, I cound it unneocerary to uee this method, as the ueual method of bleckening and fixing wa found to be ontirely atisfactory for oellophune. Li orajer to make tudy of the movenents of the trog heart, two levera were uaed simultameously. The froe wa firet pithed, and then the heart carerully expobed. Whe perioardiun was opened, and then one of the smell metal barbs of one lever wa thrust into the base of the hesrt, while the other lever was connected to the apex by the samo mothod. The levera were o. arranged thet the upper writing polnt would record cephelad and oaudad movements of the base, wh11e the lower writing polnt recorded correapondine movements of the apex. A downard movetent of either writing point indicated a caudad moverent of the corresponding pert of the heart. The levers were so constructed thet the oriting polnts inseribed twioe tho morement actually nade by the point on the heart. A reoord of the movement of the base and apex of the frog's heart is shown In $M_{8.2 .}$. It 1 seen that the morements of the base are much fropter than those of the apex. By observation 1 t was found that at each oystole of the ventricle, the base of the tentricle moves toward the apex, while the apex 1tself remalns praotioally gtatlonary. 
BASE

APEX

$1^{\prime \prime}$

Fig.2. Hovements of base and apex of frog heart. Lever magnification was $2: 1$. Time was recorded in $2^{8}$ intervals. Observation showed that the downward novement of the base ocourred auring systole.

Fig. 3 shows the same thing as Fig. 2. except that a larger movenent of the base was recorded because a larger frog was useả.

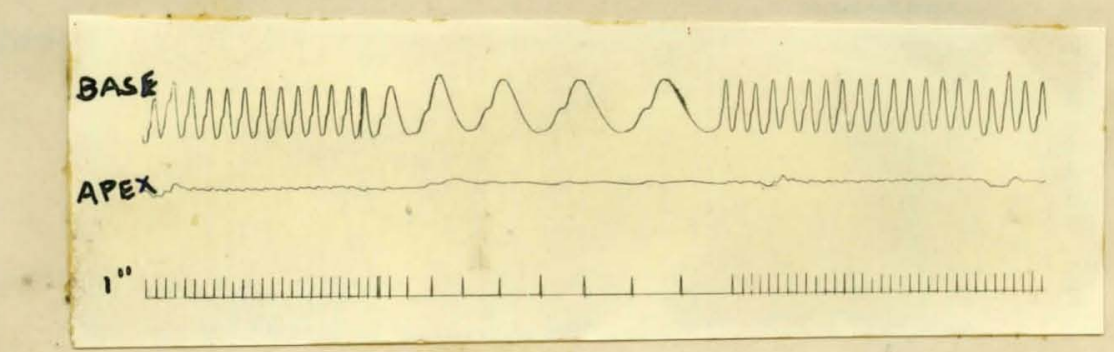

Fig. 3. Movements of base and apex of frog heart. Lever magnification was $2: 1$. Iime was recorded in $1^{\prime \prime}$ intervals. 
A study of the movements of the turtle heart was made by the same method, and it was found, as shown in Pig.4, that the base had a large cąudad movement during systole, while the apex had only a slight movement cephalad. Cutting the frenulum caused the whole heart to move upward slightly, but the apex moved cephalad much more than the base, thus erusing the longitudinal axis of the heart to be shortened. Also, cutting the frenulum caused the movement of the base to be very much reauced, while that of the apex was ususlly slightly inoreasea.

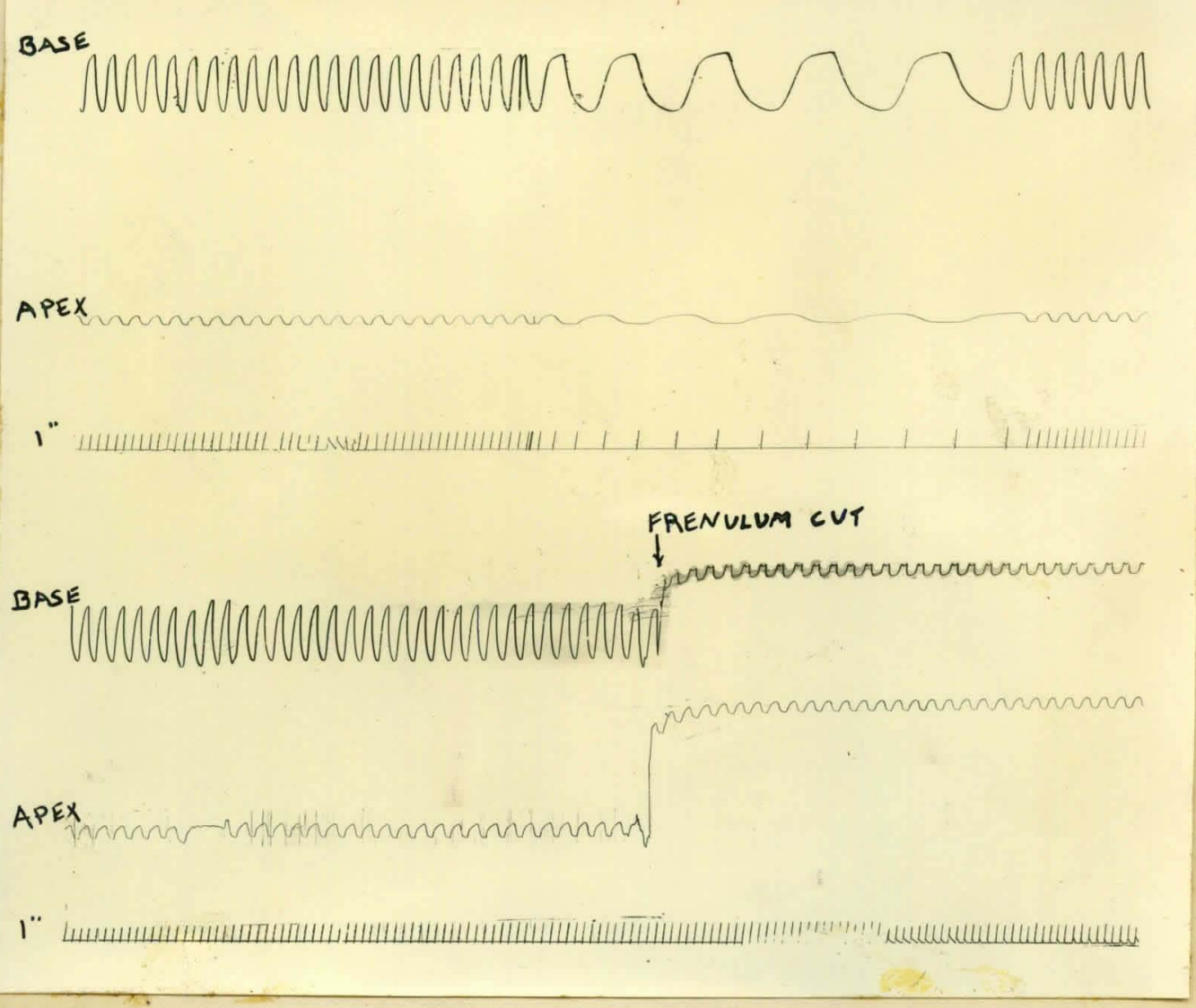

Fig.4. Hovements of turtle heart. Lever megnificetion was $2: 1$. Lower record shows effect of outting frenulam. The base and apex both moved cephalad. Novements of the base were recuced grestly, while those of the apex were hardiy changed. 


\section{COASIDERATION OF FUWCTIOR OF FRRULUH.}

In the previous atudies on the froc host it was found that outting the erenuium has very 11ttlo offoct, but this is to be expeotied sinoe it is not as highly developod in the frog as In the turtio heart. In the frog heart the fromalum cone18te merely of several delioste atrande of oonneotive tiague oonneotlne the posterior eurface of the ventriele to the perioardium, while in the turtie heart the frenulum attaches the tip of the ventriclo to oonnective tigsue, which ensheaths the liver and whioh also hes attachent to the anterior body wall. The furiot10n of the frenulum seems to be to "anchor" the apex. for each systole of the hesrt ozuses a pull upon it which 1s transeitted to the body wall. Th1s fixition of the apex allows the ventrioular musoulature to pull the base downwar at oach sygtole, for outting the fronulum recuees the caudad moroment of the base markedly. The heart is thus onobled to expend its onercy in moring blood, instead of wasting part of it in moving the curroundlng organs.

In the mamalian beart the Irenulum is absent, but ito runction is accomplished by other mesns. The mediastinum offere considerable eupport to the hourt, and the pressure exerted upon it by the lune also alds in malntining 1 to position. Hackenzie (7) has shown thet the apex of the heart is ciosely adherent to the diapragm, and that it is held practioally stationary because of the inertia of the heary abdomingl oreans. He has shown that there is a elight upware movement of the livex during ventrioular systole, but the welght of that organ makes the wovement very slight. 
In studying the movement of the $d o g$ 's heart, the same method was used, but stronger levers were employed. "The chest was opened in the mid-line, and artificial respiration given. The pericardium was opened, and one of the levers was connected to the base by the usual arrangement, while the other was connected to the apex. A pulse traolng was also recorded by placing a glycerin capsule over the femoral artery, and connecting to a Becker tambour. The record shown in Fig.5 indieates that there is about a licom. movoment of the base caudally during systole, while the movement of the apex is very slight. FEMORAL PULEE
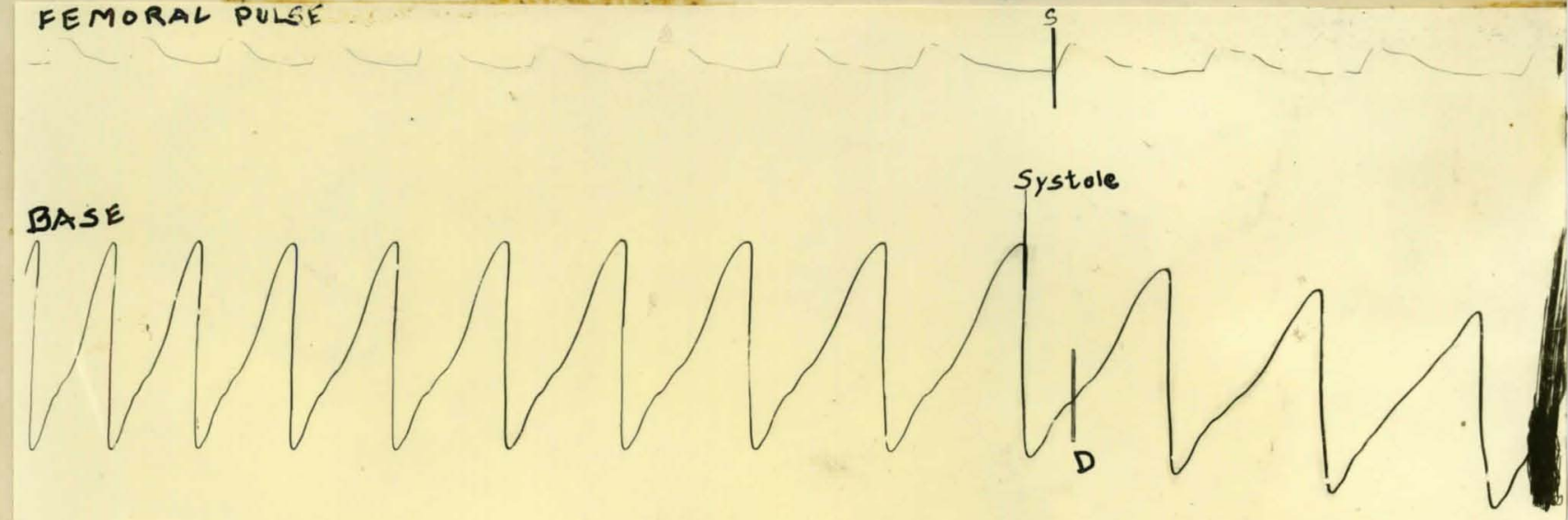

APEX

$h^{\prime \prime}$ 1 1

Pig.5. Movements of $\log _{\mathrm{g}}$ heart. Upper tracing is fomoral pulse, the second shows movements of base of heart, the third shows movemants of apex, while the lower tracing indiastes time in seconds. Perpenaioular lines show duration of systole on each tracing. Mgnification of levers was $2: 1$. 
Allowanoe must be mace in this experiment for the faot thet the obeat was open, and thwe the heart was more free to more than in the intaot animal. The ellght upwerc movement of the base toward the ond of astolo Indiontes a movement of the whole heart. Ihis is due to the faot that the previousiy distended aorta diminighes in alge and thus pulls the hest upwara. During destole the aurioular gize diminiahes, so the auriouloventrioular septum mores upward. 
FLUOROSCOPIC STUDY OF PAS MOVEARES OF THE HEARt.

The otudies by mechsnionl means of the movements of the heart of the frog, turtie, and the dog ghowed that there io a relatiroly large morement caudaliy of the bage of the heart during ayotole. whil the movements of the apex axe only slight, varying in the Irog anc turt2o bccording to the cevelopment of the rrenulum. Howover, in all these osges the heart was exposed, and therefore, In orker that conditione wight be a normel as poseible, the fluoroscoplo wethod sugeosted 1 tself for further study of the morements.

The $x$-ray ollhouette gives us an excelient ploture of the movemente of the outilne of the heert a whole, but does not differentiate between the aurtole and ventriole. Therefore, in order to study Nuorosooploally the morement of the base, anall pleoes of metal wore plaoed in varlous parts of the A-V groote. and also in the apex. Barbe were out from modium alsed fish hooke, and the shapt part of each was ground to 11 the the of a four Inoh, olghtoen gage noodle. These were then pushed through the chest wall of dog uader other anaesthesia, while observing the heart Iluoroscopioalig. The barbe were thrast into the heart wall, and then dislodged from the needie by atylet. Then the necdle wa withdrawn, they remained in the heart, beoanse their shape would not allow then to move baokward. The morement of the bazbs was observed fluoroscopioally and oharted, and finslly. their exaot position within the hest was determinod at autopay. By this method 1 was found that durine systole the base of the heart of a trecium-sized dog moved oaudally about 10.m., while the apez hac only a very slight novement. 
An oporative method wag then undertaken in pleolng motal110 objects in the heart of doge, so that thelr poaition could be known without first killing the animal. In this method the aoge were given erain morphine eulphate hypodereleally, and then the ont1re oheat wall was oaretrily oheved and washod. Ether anesthesia was given,gnd the ohegt wa opened in the midilne. the operation belng cone under aseptio teohnlque. Artiflolal reaplration was glven through a metel wask. Whioh fitted the dog's head alr-tight. The objecte plaoed in the hoart were fo.m. pleces of 16 sllver wire, which were 11 rot pleoed ineide a larfe bore needie. The needie was then thruat obliquely into the heart wall, and the ollver wiro alolodged by atylet. A entes of the objeote were plaoed along the basexof the heart and several vere placed in the apex. Three dogs girvived the operation, and fluoroscoplo and radiographio examinstion wa made of each. Fesulte of the lluoroscoplo examinations aro shown in Fig.6. Mig.7 is an x-ruy ploture whloh showe the position and movement of the objecte within the heart of one of the aogs. The results of the Finoroscoplo and $x$-ray stuales show that In the introt dog the movemeate are in accord with the findinge by alrect resording, that ta, the base of the ventriole moves oaudally bout one contlneter at ogch systole, and thls causes the ventrioular walls to thioken, for the apex 18 elmost etatlonary. Howerar, systole also causes movenent of the anterior and posterior wells of the ventriole toward each other. The net result of these movemente onlarees the aurioular oarity, and reduces the ventrioulateritfeg to a minimum, thus moet exfsolently expolitine their blood from them. 

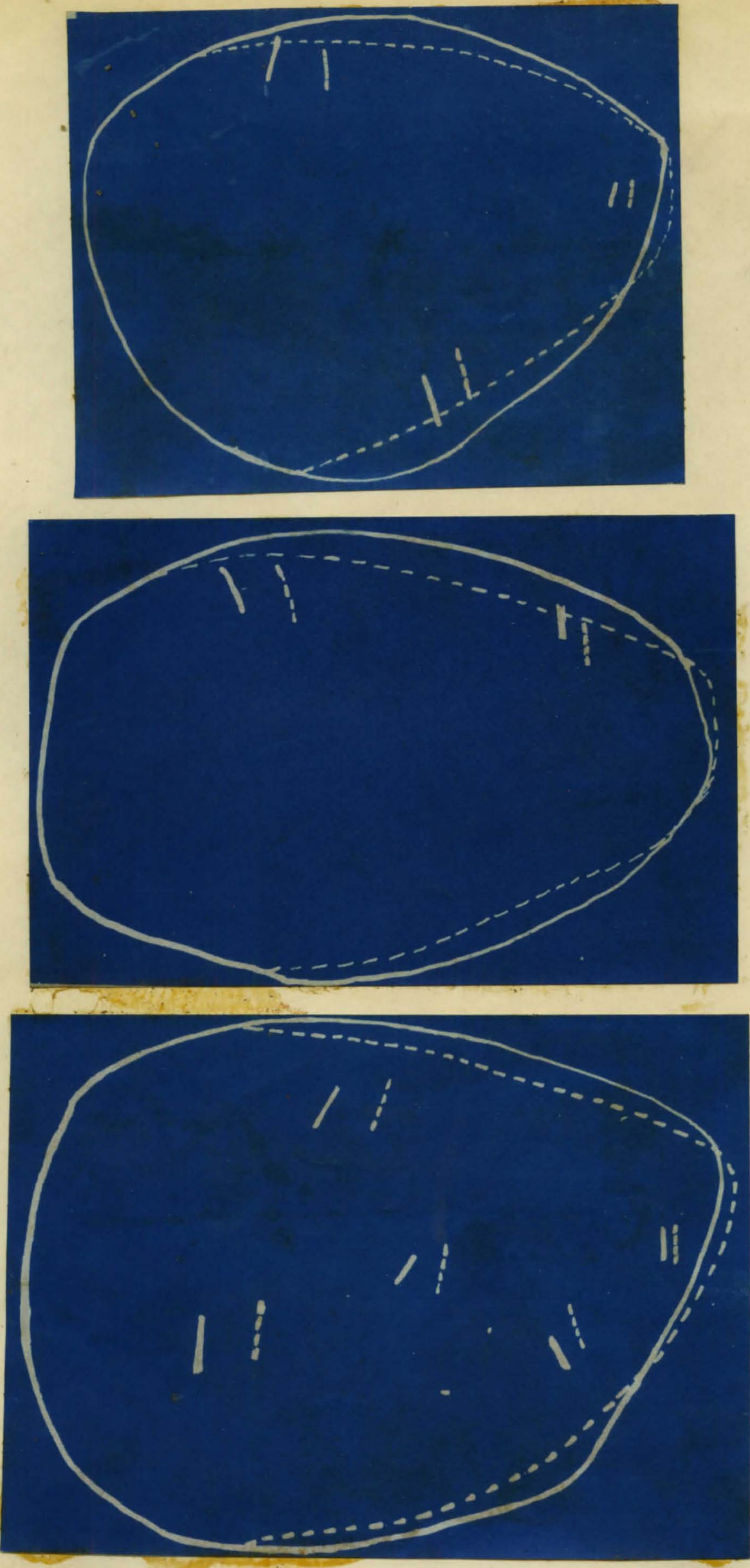

Dog. H. Hight laterel view of heart as shown by fluoroscopic examintion. Solld lines show diastolic position. Dotted Iines show systolic position.

Fig.6. Drawings showing results of fluoroscopic studies of hesrt movements. 


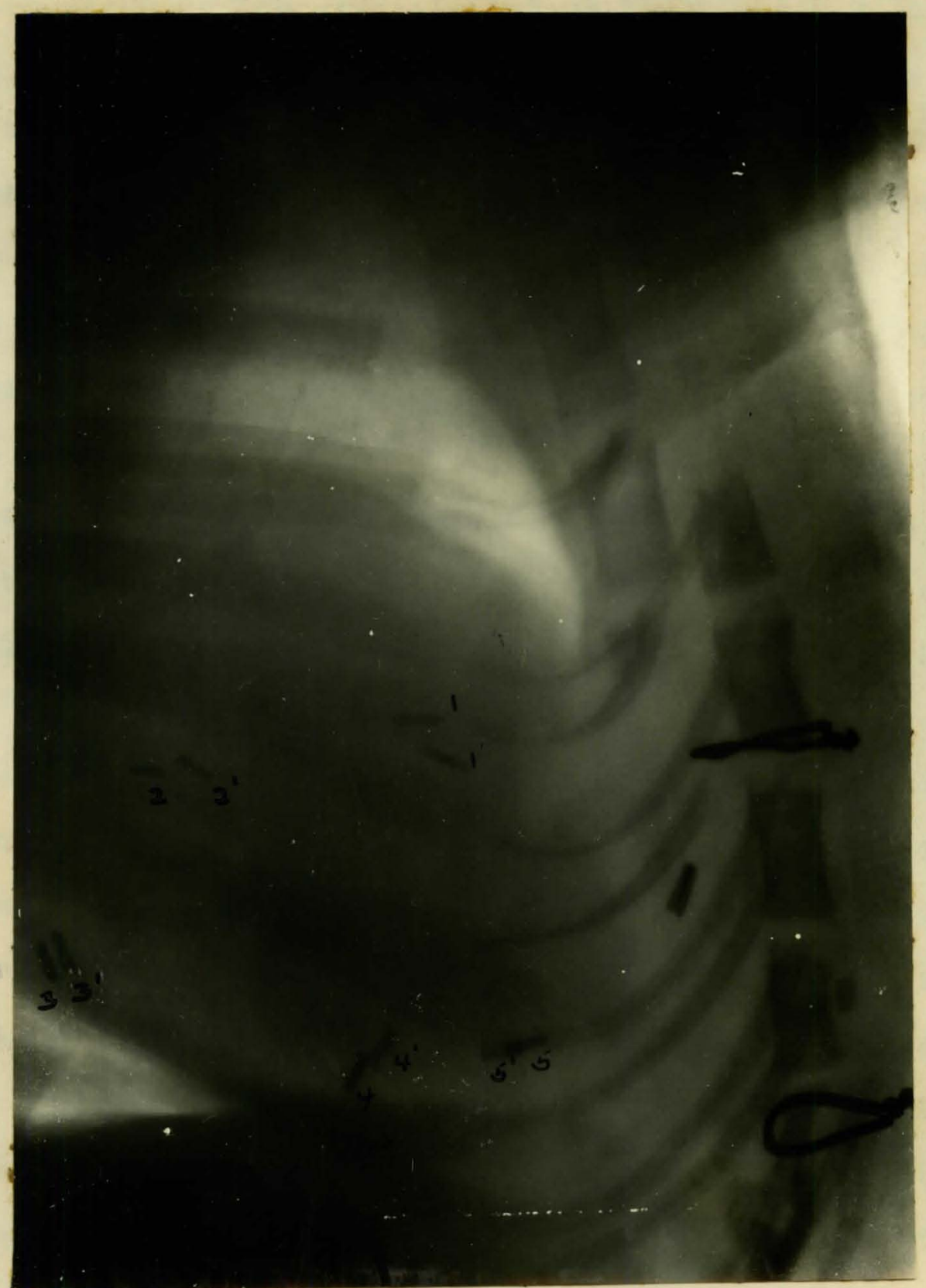

71g,7. Radiograph of right lateral view of heart of dog 43 showing systolio and diastolio positions of silver wires. The heart rate was 60 per minute. $X$-ray exposure was 4 seconds. Thuch grester movement is shown by the wires in base of heart. Large wire $100 \mathrm{ps}$ are silver wires inserted to hold sternum toesther ouring recovery. 1- wire in base of heart, diastolic position. H '- same wire, systolic position. 72 - oilver wire in posterior part of base of ventricle, diastolic position. t2' $^{\prime}$ same wire, systolic position. \#3- silver wire in posterior pert of hest, älastolic position. $3^{1}-s a m e$ wire, systolic position. f4 silver wire in posterior part of apex, alastolic position, $4^{\prime}$ - same wire, systolic position. of apex, diastolic position, ${ }^{5}$, same, systolic position. 
COMSIDERATION OF THE STOMIYICAMCE OP FLUOROCOPIC FINDINGS+ Sererel attempte $(\theta, 9)$ have been made to determine the atroxe rolume of the heart by oaloulations whloh have as thelr basis the afferonoe in area of the systollo and diatollo shadows as ahown of $x$-ray plotures. In this method $x$-ray photographs of about $1 / 40$ second exponure are made during the $R$ wave of the - lectrocaralogram and at the ond of the $I$ wave. The area of the ohadoul is mesured with planimeter, gne the volume oomptted

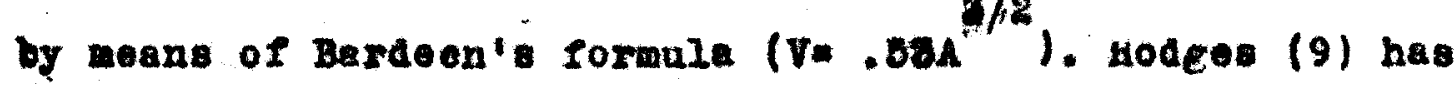
attempted to improve the method by uaine photo-0100trio 0011 to 0lose the olroult in maxing the $x$-ray' exposures, whioh in hie method are $1 / 400$ th second in auration.

wook and Byster (8) found by thelr $x$-ray mothod that during exeroloe the diatolio and syetollo sige of the heart may Inoreage or deorease, but thet umally the etroke voluae 10 increseed. Thoy found however, that in some cages there was an increased output per beat although the diastolio sise was deoreased. They attributed this to ohanges in tonus of the hesirt musculature.

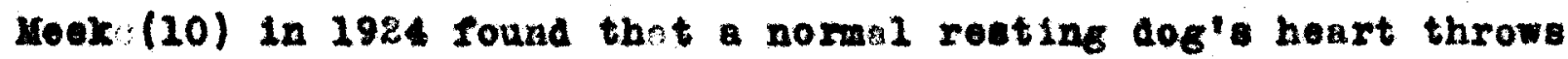
about a laxge alastollo wacow when beating at a rato of $110 \mathrm{as}$ It does at 60 , and at the ane time at the rapid rato puts out muob less blood per beat (II) However, he found that 88 the rate inoreases beyond an everage of 110, the disatolio size underfoes a rapld docrease, but if the venoug pressure 1e malntelned by perfusion the rate ma be Inoresesd as high as 200 per minute without any decrease in the alastollo size. In this work week used the same wethod as before excopt that he used Skavien's formula (12) whloh 18 a modfiontion of the Bardeen formula for use on doga, to caloulate the heart volume from the area of the disatolle heart bhadow. 
The x-ray method for determining the cardiso output es used - by Heok and Byster, and Hodges is Inoorreot, beoguse thoy were cotermining the ohenges in area of the heart hadow as a wole, and not that of the ventricles. Tho suriole oan not be aletingulghod from the veatrislo by $x$-ray examinstion. Also, ihe base of the ventriole has a groater movement oudally auring syatole than the upper border of the furieles, and this indiogtes that the total volume of the heart does not ohange as muoh auring a heirt oyole as ito etroke volume would indioate. Therefore, durIng ventrioular aystole the uurioles ast be fliling or the total volume of the heart would ohange ap oreciably. This filling of the aurieles is gooomplished by the downmard movement of the auriouloventrioular septum, whioh during ventrloulax syatolo onlerges the oavity of the aurioles, and thue slows a flow of blood into then frow the great veins.

Thie v1ew gives us an explengtion as to how slow heart may pump the same amount of blood per alnute as a fat one, and yet give the same size shadow on x-ray oxfmination. The slow heart with the lare etroke volume probably has largo ventricles and small aurioles, and the rapid host probably has more blood in the aurioles, but the ventriole takes a sealier proportion of the aurioular blood at each beat.

Hook and Byter (8) have found that the diatolio heart shadow remalne about the same during exere1ee, but Henderson and Haggard (23) and most other authoritieg have found the the stroke volume 18 inoreased. Thle problem oan be explained if wo aseum that the rapla filling of the auriolo during ventrioular oy atole oncblea the heart to pump more blood at eaoh beat without 
Inoreasing 1to diestollo 8120. This explanation aseume that the kighir venoug pressure auring exerolse fils the aurioles more oompletely durine rentrioular aystole, and they in tura are able to 1112 more complotely the rentrioles.

The finding that the base of the ventricle makes such a marked caudad movement during sybtole ad me to make atudy of the rolume ohanges occurring in the hest as a whole, and the auricle and ventriole separately, to determine if there lo any relationship between the movements and volume changes of the heert. 


\section{A STUDY OF VOLUME OHAEORS IN THE RRART}

WITH PARTICULAR RBFERBICE TO THE FILITMG OF THE AURICLB.

Current physlology texte atate that the auriole merely acte as a reservolr to reoelve the blood from the ereat reins, during the perlod when the A-r valves are olosed (14). Host texte state that the rlow of blood into the ohest occure throughout the heart ojo10, exoept during aurioular aystole. Hamilton (15) has obtalned evidence from the cardlopneumogram that the flow of blood into the thorecio cavity during ventricular ayotolo is very nearly -equal to the outflow. He also obtalned evldenoe from the obdominal plothyamogran that auring ventrioular ayatole the aboomins size dininishes in opite of the arterial expansion, thus 1ndioating that the blood in the abdominal velns flows toward the heart during systole. HolelBhner (16) has reoorded oardlopnerumorams by meens of hot wire anenometers, and has found gross volume obanger of a moh a 350.0 . In the thoraclo oavity during ventrloular systole. However, his net ohanges during syotole amount only to about 0.0. , and thua agreo roughly with Hamilton' Ilnaings.

Henderson (17) and nurerous other invertleatore have otudied volume ohanges of the ventricle by moans of a cardiometer and hevo obtained muoh ovidenoe ooncerning the filling of the ventricle under rarlous conditione. Henderson's view is that the ventriolo 11118 during diatole by Llow of blood from the veins.

Stefsnl (18) recorded changes of volume of the whole heart ueing the perioardium as a osdioweter by olmply inserting a cannula into it and conneoting with tambour, using air transm1esion. Stefent's volume curves of the whole hegrt affer from the ventricular rolume curves of Benderson and others in having 
several waves for each heart eycle. The usual type of curve obtained by Stefani consisted of a sharp downstroke during ventricular systole, and then an upstroke which was in two phases. Stefeni interpreted the downstroke as being due to ventricular systole, and the first phase of the upstroke as being due to diastole. However, he did not publish a simultaneous pulse tracing, and therefore, it is not certain that the eirst phase of the upstroke really ocoured auring distole. Also, from his Curves . it is apparent that he ald not allow a suficient time for ventricular systole, for the primary phase of the upstroke really appears to be within the period of systole rather than diastole. Wiegers (19) has obtained numerous records of intra-auricular pressure, and acoording to his results, there is a sharp fall in intra-aurioular pressure during ventricular systole. Fig. 8 gives a typieal intra-auxicular pressure curve as recorded by

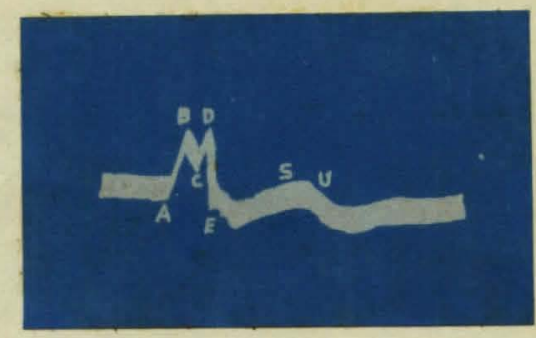

- FiE. 8. Record of right intra-auricular pressure as recorded by Wiggers. (Page 32, Pressure Pulses In the Cardiovascular system) $A-B-C$, auricular wave; $C-D-\mathbb{S}$, early systolic wave; $S$, end of ventricular systole; $U$, onset of right ventricular inflow. R Burton-0pitz (20) by messuring the flow of blood through the external jugular vein has found that the flow is ten times as great curing the period $B$ to $B$ on $F i g .8$ as it is at any other part of the caraiac cycle. 
PROCEDURE A study of the volume changes was made on the frog. turtle and $\log$ heart. The spparatus shown in $r i g .9$ was used to recora the volume changes of the frog and turtle hearts. The tambours consisted of hemi-spherical shaped saos of thin rubber, upon which a very light lever of balsa wood rested. "The lever was partially counterbalanced and was supported by a pin pivot to increase the sensitivity. A water manometer was connected to each of the tambours, ana the tube A connected the two. Air transmission was used in the system, \& large syringe being used to inflate the system to the proper level, while a 1 c.c. tuberculin syringe was used for calibrating. Suitable magnification could be obtained by regulating the distance from the fulcrum at which the jever touched the rubber eapsule.

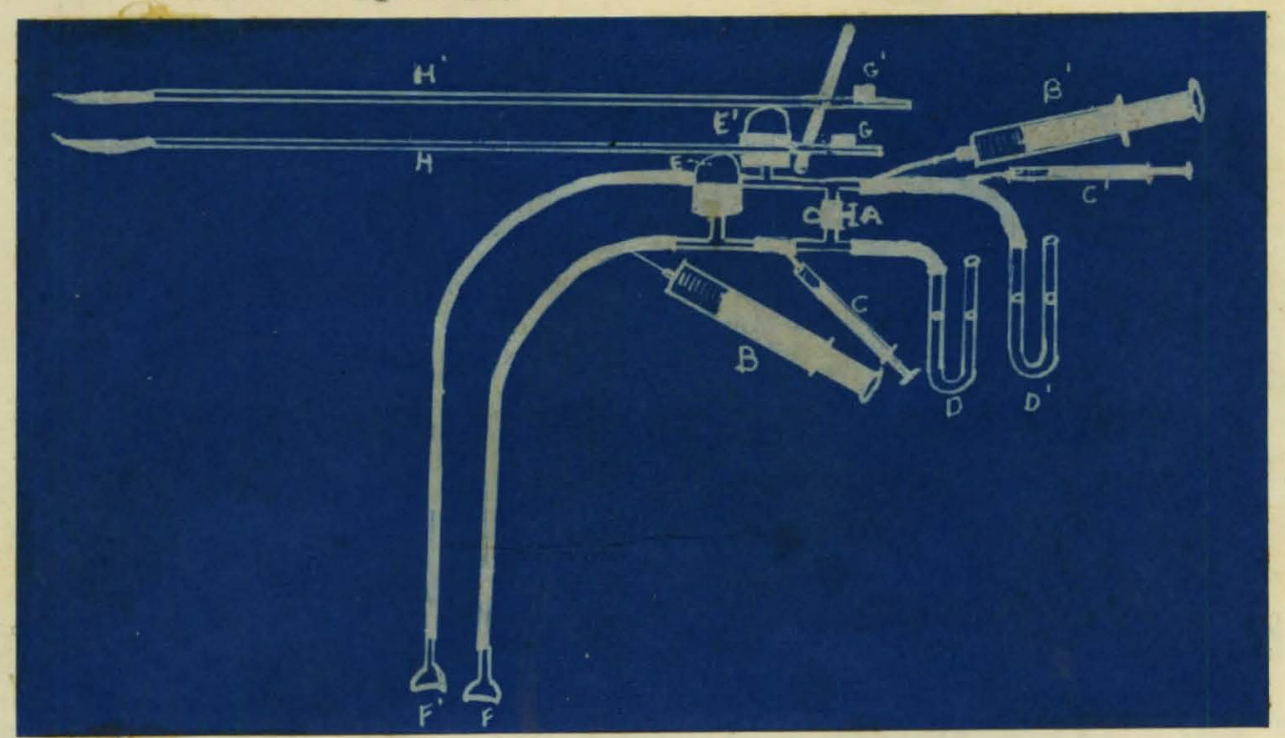

Fig. 9. Apparatus used for measuring volume ohanges in the frog and turtle heart. $A$, tube connecting the two systems. $B$ * $B^{\prime}, 200.0$ syringes. C \& C', lc.C. tuberculin sysinges used for calibrating. $D \& D^{\prime}$, water manometers. $\mathbb{E} \& \mathbb{E}^{\prime}$, thin rubber tambours. $F$ \& $F^{\prime}$, Elass cup cardiometers, G \& G', small welghts used to partially counterbalance levers. H \& $H^{\prime}$, Balsa wood levers. 
For the stuay of the frog's heert large msle frogs weighing from 1 to $1 \frac{1}{3}$ kilos were used. The frogs were first pithed, and then the heart was exposed, care boing taken to avo1d hemorrhage. A large bore glass cannula was then inserted into the pericaraium and connected to one of the recorders. Fnough air was injected into the system to distend moderately the pericardial eavity, but not to raise the pressure over 2m.n. of water. A record of the volume changes as shown in Fig.10 wes obtained. Calibration was made by inje ting . 1 3.c. portions of air into the system and then witharawine them.

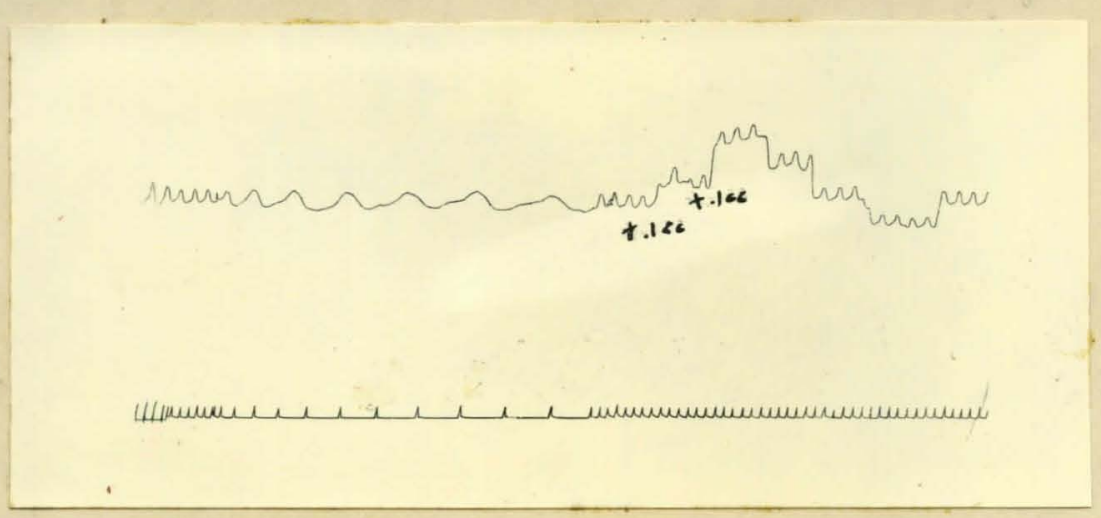

Fig.8. Volume changes in pericardial cavity of frog. Calibretion in terms of .1 o.c. oir injections and withdrawals. "Iime is recorded in one second intervels.

Next, a small glass cup was placed over the entire heart, core being teken that it exerted but very little pressure. The oup was then connected to the volume recorder, and as shown in Fie.ll the roc ras obtained were very similar to those obtained using the 
pericardium as a cardiometer. Slightly larger volume changes were recorded, due to the frenulum pulling tissue into the cardiometer at each systole. However, in spite of this the volume changes amounted to only about. . c.c. while the average figure obtained using the pericardium as a cardiometer was .04 c.c.

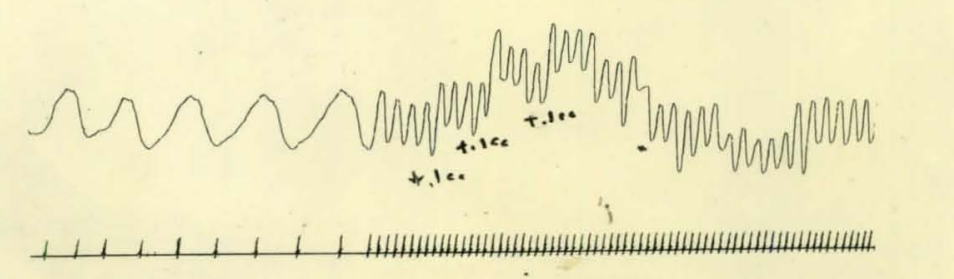

Fig. 11. Volume changes recorded in esriometer placed over whole heart of frog. Galibration in .l c.c.

Simultaneous volume chances of the suricle and ventricle of the frog's heart were then recorded. Two small glass cups each of which had one edge flattened were used. One of the cups was lightly placed over the auricle and connected to one recorder, while the other was placed over the ventricle and connected to the other recorder. The flattened edces of the cups were contiguous, any lay in the atrio-ventricular groove. By this means a sirnultaneous record of the volume changes of the auricle and the ventricle was obtained. "As shown in Pig. 12. as the volume of the ventricle aecreases, the volume of the suricle and sinus venosus increases. A very good demonstration of this was made by opening the tube A connecting 
the recorders. Immeditely the movement of each of the levers was almost stopped, showing that the volume change in the ventricular recorder was neutralizing that of the aurieular recorcier. When the connecting tube wais closed, each of the recorders immediately inseribed its previous record. Also, it is seen by a comparison of the volume changes shown by either the auricular or the ventricular recorder in Fig. 12 with the total heart volume changes as shown in Fig. 10 and Fig. 11 . that the volume change of the heart as a whole is very smell as compared with the auricular or the ventricular volume change. .

AURICLE

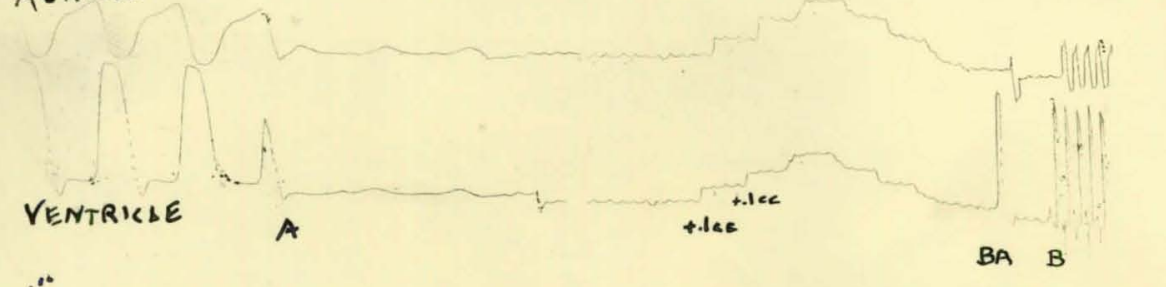

$i$

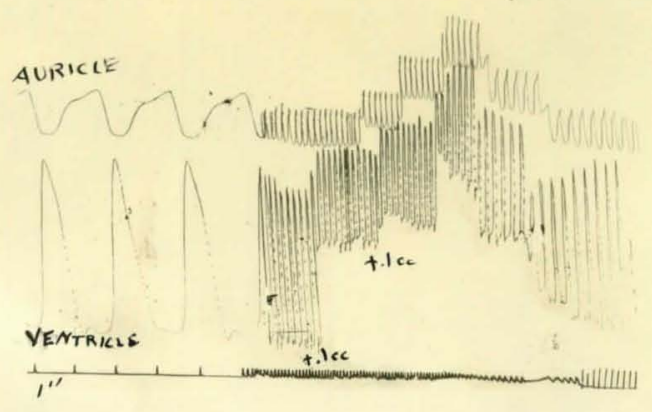

Fig. 12. Simultaneous volume curves of the auricle and ventricle of the $\operatorname{lrog}$ heart. At $A$ the tube connecting the recording systems was opened. Calibration was made by .le.c. air injections. At $B$ the tube was closed again. Lower recora is continuation of upper in which usual callbration was made. 
Alwo, It mut be romembered that the volume obane of the auriole or ventriole alone as determined by this method is 10a than that ooourrine in the inta ot animal, for the allght preseare of the glase oup hincere the How of blood. Horeover, the auriole fills more in the Intaot anioal during aystole of the ventriole, beciuse the pressure of the oaralometer" in these experinents outs down the flow of blood toward the hoart wore than that away from 1t, beoguse of the thinness of the wal18 of the velne as compsired with the arteries.

When the oardiometer is placed lover the whole heart very Iittlo pressure noed be splied to make tho syatem air tleht. and therefore there io only a very sllght impodiment to the blood llow. Ih1s is shown by the reot that the volume ohanges determined by ualing the perloardium a oardiometer segreo olosely with those obtalned using the glaes oup orralometer. 
VOLUNE CHANGES IN THE TURTLE HEART+

The same appar tus was used to record volume changes of the turtle heart. Large sized turtles were used for these experiments. First, the brain was destroyed by orushine, and then the plastron was removed earefully, so as to avoid hemorrhage. A large bore glass eannula was then insertea Into the pericardium and tied: Volume chenges were reoorded as shown in Fig. 13. Calibration was made in the ugual manner.

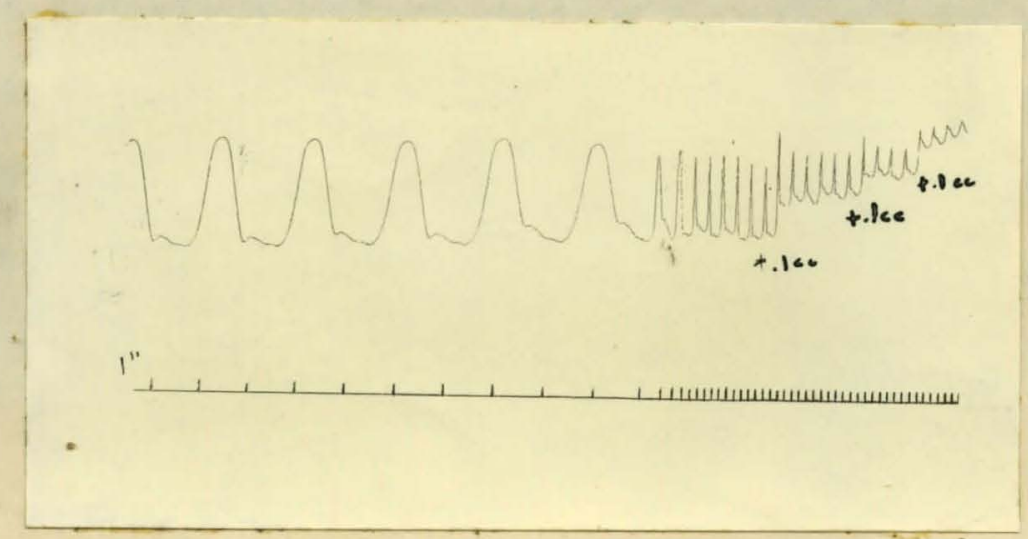

Fig. 13. Volume changes in pericardial sac of turtle. Calibration in .1 c.e. Time was recorded in $1^{*}$ intervals.

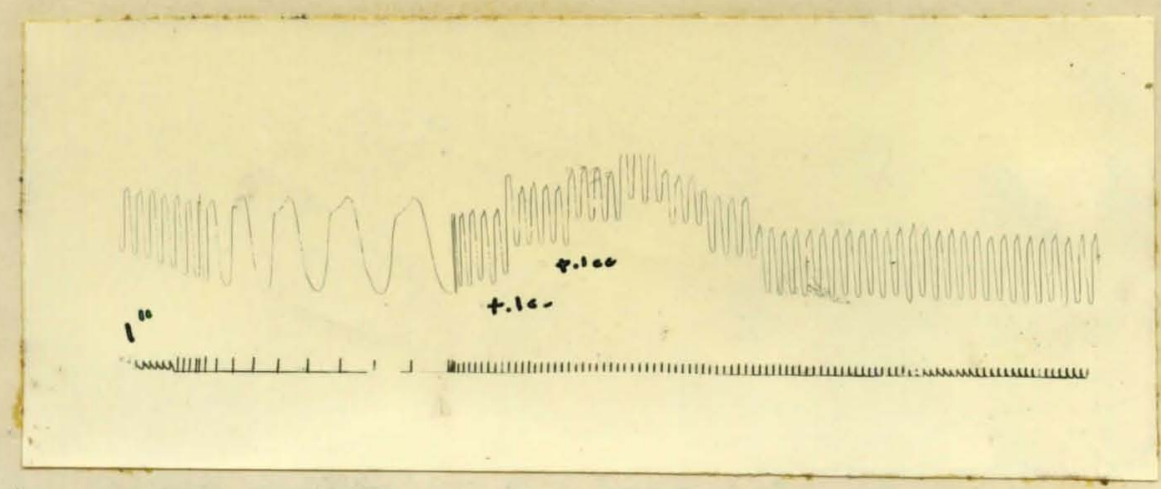

Fig. 14. Volume changes of whole heart of turtle using glass cardiometer. Calibration in .1 c.c.

The perioardium was then opened, and a small glass oup was placed lightly over the whole heart and connected to one of the volume recorders. A recoed of the volume changes $\varepsilon$ a shown in FiE. 14 was obtained. A slightly laxger volume change was 
recorded by this method because at eich systole the frenulum pulled tissue into the cardiometer. However, in spite of this the volume changes obtained using the pericardium as a carlometer agreed roughly with those obtalned using the glass cup caraiometer.

Finelly, a record of the volume changes of the ventricle alone was recorded by placing the glass cardiometer lightly over the ventricle and connecting to one of the recorders. It was necessary to cut severs indentations in the edze of the eless cup so that it would not cut off the flow of blood in the arteries and veins. Pig. 15 is a record of the volume changes of the ventricle alone.

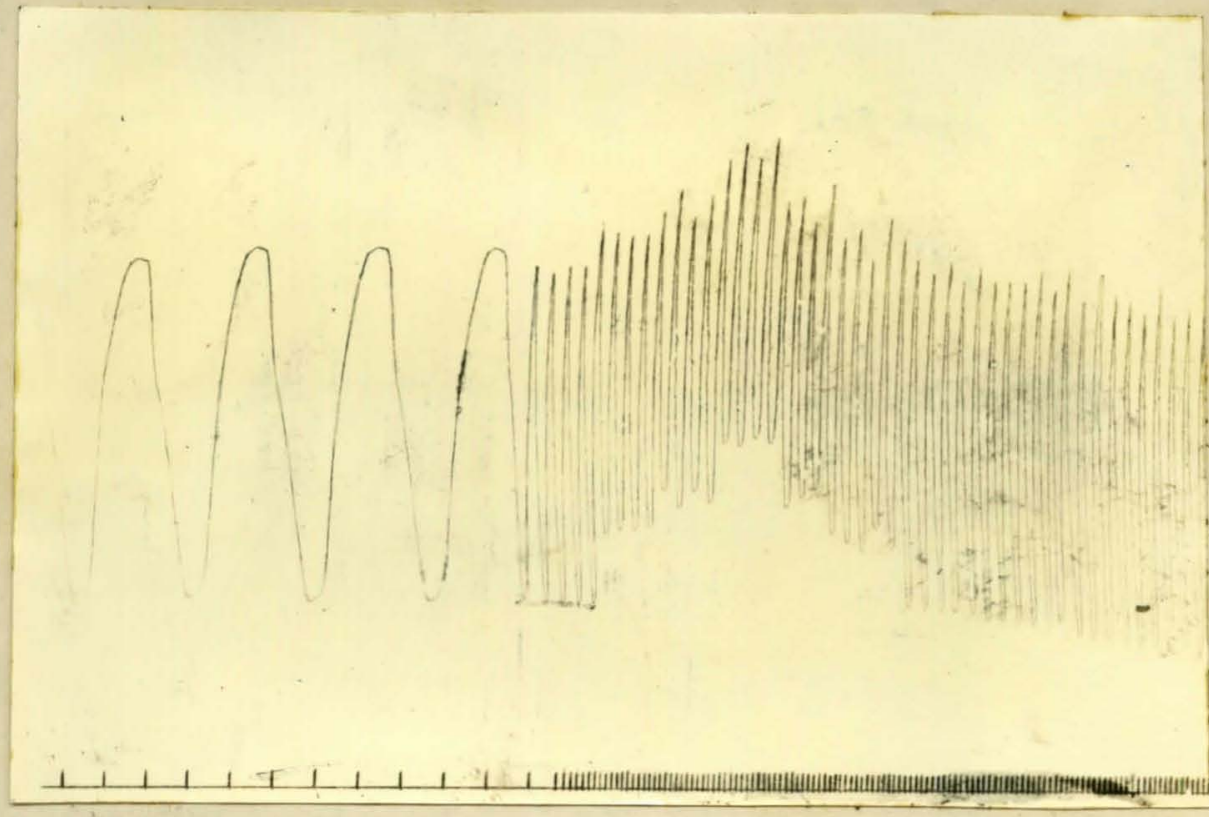

Fig. 15. Volume change of the ventricle of the turtle heart. Galibration is in .l c.e.

I was not able to obtain simultaneous volume change records Q2 the auricle and the ventricle because of the Ereater complexity of the turtle heart. However, by comparing the ventricular volume changea with the total heort volume changes, it is easily seen that the auricle must be filline completely as the ventricle 
omption for the volume ohange of the whole heart to remain so

- Ion (.2 c.0.) while the ventricular volume ohange 10 so erest $(.70 .0$. 


\section{VOLOAR CHAME? OP THE DOG HEART.}

The cogs were ansesthotized either with ether or by clving them $200 \mathrm{m.8}$. of sodium barbltal per kilo intravenously. The ohost wa opened in the midine, oare being taken to avola hemorrbage. Artifloial respiration was glven by weohanleal moans through a traohes oanunin. A glabs osnnula wa insert-d into the external Jugalar veln, and had a tube so arranged that the venous preseure could be determinec by the rise of bluod within it. Connection was made to a perfusion bottle I1lied with warw laotonio celine so that the venous presenre could be $r$ laed by perfusion.

4 osnuula was inserted into the porioardiam, and connooted to a large tambour, which hat a 10080 thin rabber membrane. The oannule used conalsted of a threaded brams tube whioh had a large bres washer soluered to one end, and also another washer and nut on it. The contleuous faoes of the weshers were covered with rubber. water manometer was connected into the system, so that large preseuro changes in the recordIng byetem could be detected and aroldod. Two byaned were 2180 connooted in the recording syotem, IsxE (EC O.c.) ane to regulate the aystem to the proper level for reooraling by Injection of alx, and small (20 0.0.) one for calloration of the rolume changes.

A ollt wa made in the perieardion, and then the ond of the brase osnnule was buttoned through 1t. The 10000 washer was then slid down and tightened. By this means it was poselble to have an alrtight communication with the perloardial oavity. without much daneer of the movements of the heart pu'lling the oanaula out or tesring the personralum* 
A series of recorus of volume changes within the pericardial cavity under various degrees of venous pressure and also under vagus stimulation were mace. A simultaneous pulse record was taken with a glycerin expsule over the femoral artery and recorded by means of a Becker tambour. Figures 16, 17, 18, 19 20 show a series of volume curves in which the wave due to the filling of the auricles ocours at various places in the heart eycle. This wave is designated $V$ on the recoras. In all cases some fllling of the heart occurred before the end of ventrigular systole. Care was taken to keep the air pressure in the recording system below 1 c.r. of water pressure, this amount being necessary to distend the pericardium suffieiently for accurate recording.

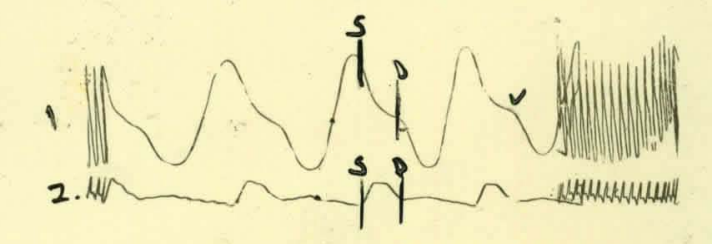

3.

Fig. 16. volume change in pericerdial eavity of dog. Heart rate is 120. 1. volume curve. 2. Femoral pulse tracing. 3. Tine in $1^{n}$ intervals. S- beginning of systole. D- beginning of diastole. V- wave due to filling of aurieles during latter pert of ventrieular systole. 


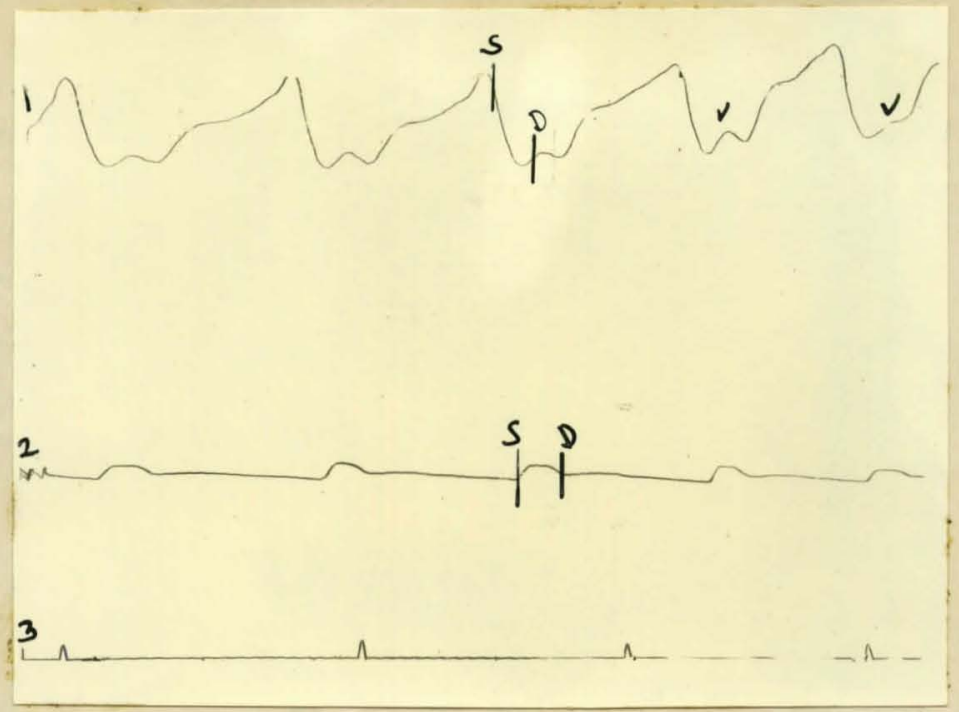

Fig. 17. Volume shanges in pericaraial osvity of dog. Heart rate is 80 . 1. Volume curve; 2-Femoral palse; 3- Time in $1^{n}$ intervals. S- beginning of systole; D- beginning of diastole; $V$ - wave on volume curve due to filling of auxicles during latter part of vontricular systole.

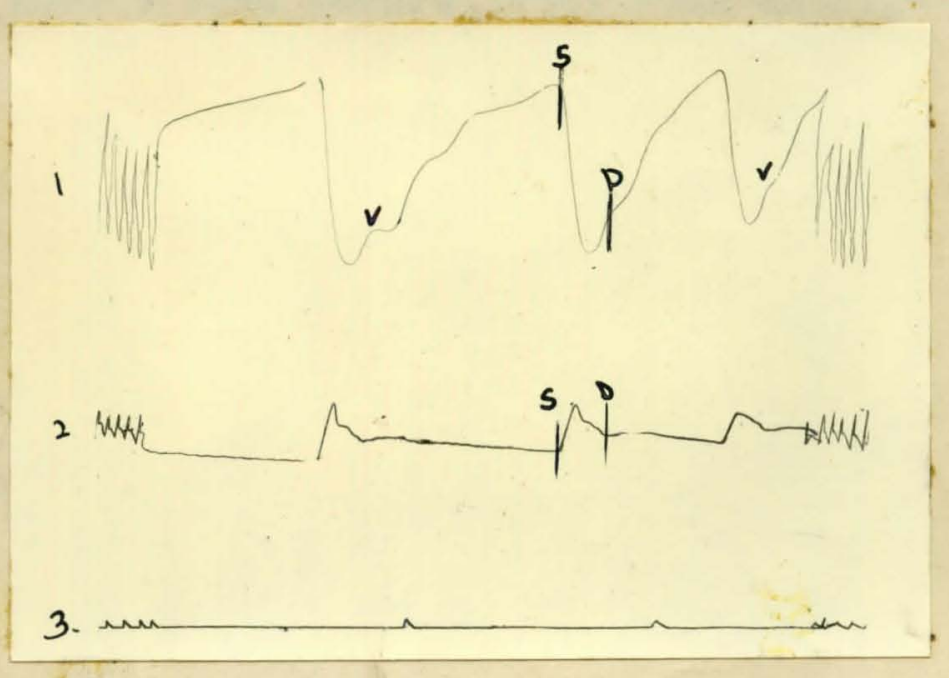

Fig. 18. volume changes in pericardial cavity of dog. Fulse rete 1s 80 . 2-Volume ourve. 2-Femoral pulse tracing. 3. Time in $1^{\prime \prime}$ intervals. S- begiuning of systole. D-beginning of diastole. V- wave due to filling of auricles. 


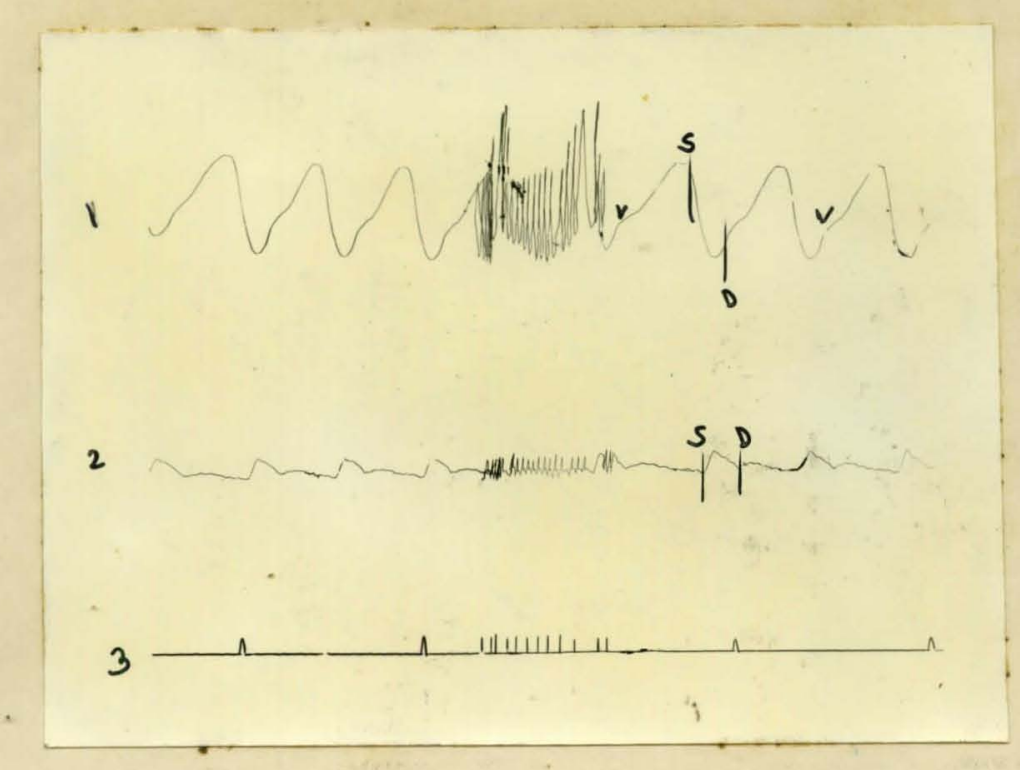

Fig. 19. Volume changes in pericardial cavity of dog. Pulse rate is 120. $V$ wave ocours later than in Fig. 18.

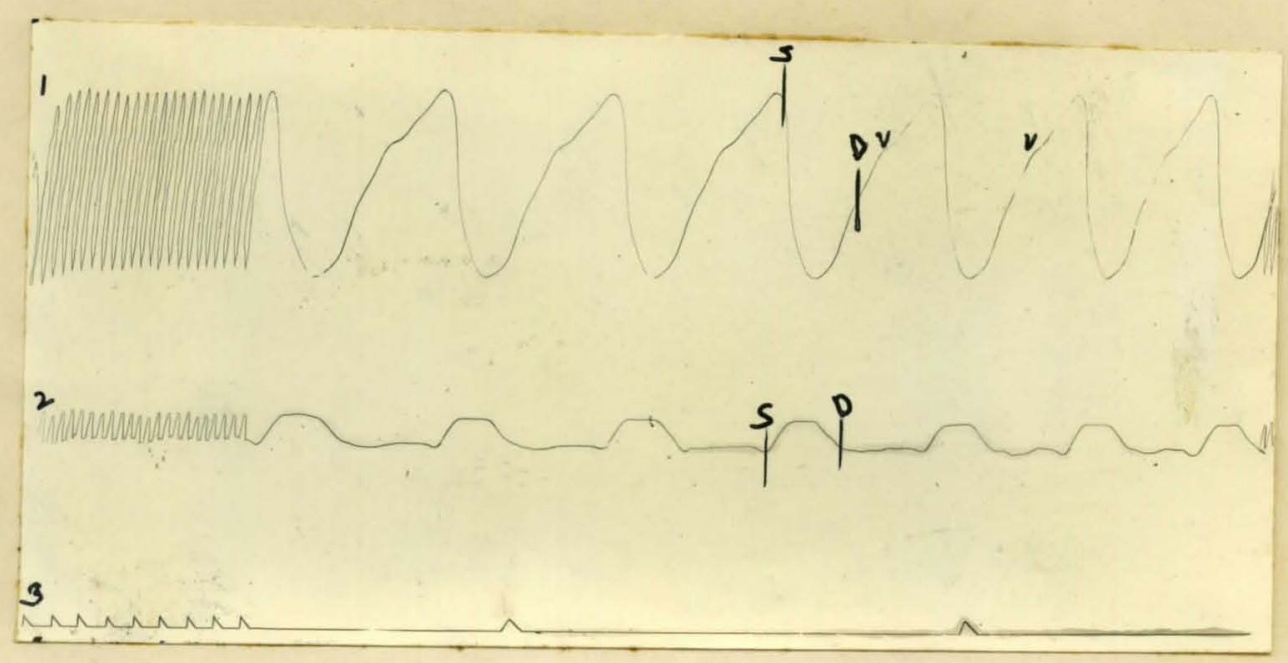

Fig. 20. volume change in pericardial cavity of cog. Pulse rate is 120. In this tracing the $v$ wave is very much later. 
Later, In order to determine the delay in tranemiselon og the pulee ware, ordiomoter was placed oror the ventrieles alone, and a volume curve of the ventrioles wa taken aimultancously with the fomoral pulse traolng. By this woans it was found that the trangmisaion time was negligible, amounting to less than one-twentleth of a socond.

It must be considered that results obtained using the perloardium a oardiometer only indicate the tendenoy of the surioles to f1ll curing ventricular gyatole. When the ohost is opon, as 18 nooessary in plothysmographio studies, the foroes and natomical relationehips which produce aystollo 11111ne of the aurioles are partlally remored, and the nogative Intra-thoraolo preseure whloh normally alde in filling of the boart is loat.

stuales of the volume ohanges of the heart uring the perioardium a caralomotor may easily give mieleading resulte. Moversents of the lungs often ouuse them to prese sgalnst the

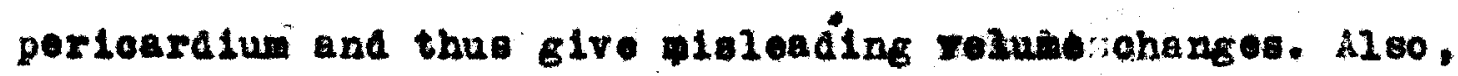
sometimes the boart moves agalnat the mouth of the cannula and oloses 1t. Thle causes a reoordise of only part of the volume ohanger, a plateau being shown on the record while the camnula is olosed. In most cases the respiratory movements oun be stopped by producing apnea through overventilation, and 11 this falls ourare may be used to stop all movement of skel-tal musole. Records which show artefaets dus to intermittent alosing of the ennula on be disregarded.

Venous pressure plays an inportant role in filling of the 
- aurioles, for unlese it is normi, very 11ttle filling ooours during ventrioular ayatolo. The downward movement of the ventrioular bae on 1111 the aurioles only if there 1 a euffiolent blood evallable in the great reins.

Sterani (18) divided hlo oardio plethyamograms into: (a) A rapidy desoenaing line which colnoldes with the period of gyatolio evecuat10n; (b) A raplaly eocending line whioh he Interproted as correaponding with the perlod of cotive diastores (0) A lowly asoending line which oorresponds to the period of passive diatolo and preayetolo. However, h1s firat and seoond perlode inolude about one-thire of the heart oyole, and thus tho socond period is probelly still during eystole. The plethysmograms shown In Figs, 16 to 20 are very similar to those obtalned by stefanl, but the simultanoous pul be tracings show that the second period of Sterani represents a filline of the aurloles during vontrioular syotole As abown in P1gs.16 to 20 this aurloular flliling say alter the volume ourve of the whole: neart ta a varying degree.

Caralo-pneumograne give us evidenoe that the intra-thoracie volume in man varies at the most only 50.0 . during oystole, whi20 over 100 a.c. of blood leave the ohest during that period. Study of oarulo-pneumograme fives ue the same ovidence for man that plethysmographio studies give indioations of in animais. that 18, thet curing ventrioular systole the aurloles nust be filling to an extent which is comparable with the amount of blood lading the rentrioles. 


\section{CORCHUSIOAS}

A atudy of the noveants of the base and the apex of the heart of the frog. turtio, and dog ahowed that during ventriaular ayetole the bese has relatively great wovement towsid the apex, while the aped remalne almost etatipnary, 1te slight morement usually bolng toward the base. The raot that the base of the heart has e great movemont, while the apex romelne almost atationixy, allowe the heart to expend all of Its enory In moring blood, ingtead of wating pert of it in moring the surrounalng orgene. In the thwt peart ospeoseliy it was found that outting the eremine oqued a great diminution of the movement of the base, but osuees allght jnoresee in the movements of the epex. It appears that id the heart of amphibiane and reptiles the srenulum has the funotion of flxating the apox. In mamale the frenulum 18 abeent, but the faot that the ohe ot 18 rigla completoly 1111 a structure makes it unnecessary. for the apex of the heart is heldogalast the diaphragn (7). A100, In mamale the medietinum offers grenter eupport to the heart.

Fuoroecoplo studies of doge with sirer wirea placed at var1ous points in tho hoart muolo confirmed in the intact animal the results obtained in eate experirents. The morements of the base of the heart downward auring systole providge and explanation a to the mechansed of the riling of the our1010 durlng that poriod. The base of the heart $110 \mathrm{~s}$ between the surloular and ventrloular portione, and the downward wovement of the eurloulo-ventrioular eeptal diaphrig enlerges the venous recervolrs allowing a How of blopa into them aring 
ventrioular syatole. As the base mores upward, the blood acoumulated in the venous reservolra, rushes into the vantrioles, and thus this explaine the rapid rentrioular filling wh10h ocours.

Th1s view that the aurioles fill during ventricular aystols more oompletely than proviously supposed is compatible with oxtdence obtalned Irom many other experiments. Nigeers, and most other workers in the field of proseure reoording, Iind thet during ventrioular aydole the intra-aurioular pressure falls to 1ts lowest level, and alsp, thet it gradually rises, until at the beginning of aleatolo, It has reached lovel whioh permits repla ventrioular fliling. This 16 ahown in Fig.8.

Cardio-pneumograms obtsined by Ham1lton (ID) and Holelohner (16) Bhow that the re ia no great net rolniw ohange in the thoracto cavity auring rentrioular systole. This can be deaonstrated very simpig if the pouth 10 f1lled wita aroke, and the Interial aares elosed with the cort palate while the reapiration 18 hold at a pasive oxpiratory standetill with the glottig open. A series of tiny pufts of smoke $18 \mathrm{su}$ from the mouth, and it oan oasily be seon that their volume 18 very minute. The impleat explanation for the faot that the intrathoracio volume remalns pratically constant during ventriculer systol. is that blood is entering the ohest almogt as fast as It is loaving 1t, the ollght difference causing pulsatilo variation of intra-thoracio volume.

Reoords of the sinultaneous volume changes of the auriolo and ventriele of the frog heart as shown in Fig. 10 show very olearly thet the aurlole fillo as the ventriclo empties. 100, 
oalibration shows that the aurtele or the rentriole alone has a moh greater volume ohange than when both are in the ocrdlometer together. In the turtio heart the volume chanfe as ahown in Fie. I6 showe that the vantriole alone change its volume.7 0.0. at each bees wh1le the whole heart volume change 18 only .2 0.0. as ahom in Fig. 13 and Fle. 14.

volume ahanges of the dog heart as recorded by tambours conneoted with the pericaralal oavity ahow a wave whioh 18

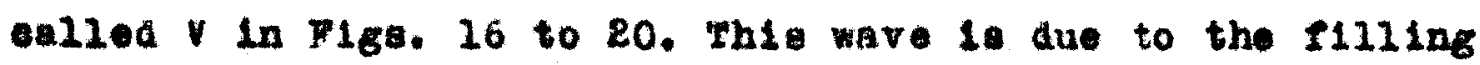
of the aurlole and oocurs near the' end of eystole. The rest of the upstroke on the re rolume recorda ladicates olower Plline of the heart, but in all oases filling of the atrlold has prooeeded considerably before aystole lo completely over.

The ceneral conoluelon arrived at we a result of stuay of the woverents and volume chenges of the heart 18 that during byatole the base of the heart woves toward the apex, and the venoug reservolra are enlarged by this mothod so that a lareo gukatity of blood llows into them before ayatole 1 s over, and their elastio reooll forees this blood into the rentricle at the beglnning of diagtole, and is aided by the upwerd movement of the base. 
SUMGARX.

1. Direot rocording of the movementa of the base and apex of the heart of the frog, turtle, and dog showed that at each systolo the bese of the heart makes a large movement toward the apex, whilo the apex remaine almost stationsy. This enables the hoart to expend its total onerey in moving blood Instead of wating part of it in movine the surrounding oreans. When the erenulum of the frog or turtle heart is out, the movements of the bese are decreased, whilo those of the apex are 1noreased. Aleo, the whole heart mores upward to a varying agree depending upon the development of the frenulum.

2. Fluorosooplo observation of the heart of coge in whioh e1lrer objects had been placed showed that at each sybtol. the beso makes about aentimeter movement towara the apex, while the apox 1 t8olf rema ins almost motionlese. The movements of the base are ereater than the movement of any of the bordera, and this suegesta that the downward movement of the baso has sientflosnoe in the filling of the aurieles.

3. Volume studies on the heart of the frog show thet the rolume changes of the heart as wole are muoh $108 \mathrm{~s}$ than those of the auriole or the ventriole alone. Also, slmultancous rolume reoords of the euriole and rentriole of the froe heart show that as the volume of the ventricle deoresees, the colume of the auriole is inoreasine.

4. volume studies of the heart of the turtle show that the volume ohange of the ventriole lone $(.70 .0 .1$, a recorded by a cardiometer conreoted with a tambour, are far ereeter than those of the whole heart $(.20 .0 .1$ 


\section{SUUR:ARY (Cont.)}

b. Volume changes of the $\log ^{\prime}$ 's heart recorded using the perioardium a cardioweter ohow that during syetole the volume of the heart decreases, and before syetole has anded, it inoreases to a varying degreo depending upon the rate and vonous prosaure. This inorease 18 due to the I11ling of the aurioles, and this I1111nt proeseds to a muoh ereater oxtent during ventrioular gyatole than prevlously supposed. 


\section{BIBLIOCRAPEY}

i. Harrey. Willian; Anatomical studies on the Motion of the Heart and Blood, 1628, Tranelation by C+D. Leake, 1931. C.C.Thomas Co., Springtield 111., page 25.

8. Starling, BtH, Human Fhyslology (1930 Fdition), page 72a.

3. Luolan1, L. 1912, Human PhyB10108y, vol. 1, pace 186, English tranalation, Haomillan Co., London.

4. 16Eers, C.S. 1928, Presaure Pulaes in the cardiovisoular System, paEe 51, Longmane, Oreon H Co., Now York.

5. Lew18, Thomad, Hovements of the Heart's Axlo with Resp1ret1on, 1924, heart, $x$, page is 7 .

6. V1secher, H.B., Flohert, W.F., Ehlenes, T.H.; Two Inprovments in the Technigue of Krmogteph fecoraing, solence, Jan. 1931, vo1. IXXXIII, No.1882, page 99-100.

7. Hackenzie, J. 1923, Disease of the Heart, and Rdition, London.

8. Meok, H.J. Eyster, J.A, E. 1923, Ameriean Journal of Phys10106r, 1x111, pace 400, Cardiad a1ze and output in man during rest and moderate exeraise.

9. Hodges, F,J., Radiology 10, pages 122-12S, Pob. 1928.

10. Hook, W.J., 2924, the Exfeots of Chanees in Pulgo Kate on Dlaptolio heart a1ze, Ameriosn Journal of Physlology, vol. 70, pege 385. 1924.

11. Maroha11, B.K.Jr., 1926, A.S.P. 1xxv11, pege 489.

12. Skavlem, J.H., 192R, getination of Cardiao volume in the Living Anlanal by means of the releroontgenoersm, Ameriosn Josrnal of Fhyslology, Vo1.61, pae t01, 1922.

13. Henderaon, Y, Hageard, H.W., 1925, A.J.P.,1xxi11, page 193 
24. Dayl16s, W. M., frinolples of Ceneral Phy8lology, 1924, Wongmans, Green, $C_{0}$, pece 677 .

Starling. B.H., Human Fhyslolog (1930 Baltion), page 734, Lea Febleor Co., Ph1ladelphia.

Howell, K.H., Text Book of thy $1010 \mathrm{gg}$, page 560, 1927 Edition, F.S. Saunder Co., Philadelphia.

25. Hamilton, W.F., Hilling of the Dormal Heart in Kelation to the Cardlopnoumogram and Abcominal Plethyomogram, Amerioan Journal or Physiotogs, vol, 91, vo.2, Jan.1980.

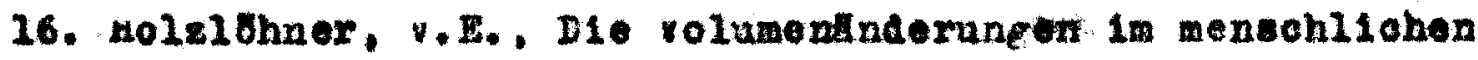
Thorax wahrend der Hersaktion, Leitsohrift rur Blologie, Vol. 92, No.4, Nob. 1932, page 298.

17. Henderson, Y., 1906, Amer10en Journal of Physlology, XVt, pace 325.

Henderson, Y., Volume Changes of the Hedrt, Hhyslological Rorlows, Vol. 111, No, 2, Apr11 1923.

18. Eterant. In twolant, L., 1911, Human Hhys10logy, vol.1, page 216, Englioh translation, Meonilian a Co. London.

19. W1680r8, J.J., 1923, preseure Pulses in the Garaloveseular

- Systea, page 32, Longnans, Green \& Co., New York.

20. Surton-0pitz, K., "qhe Flow of Blood in the Fxternil duguler Vein". Anerioun Journal of Phys10logy, Vol, 7, page 435,1902 


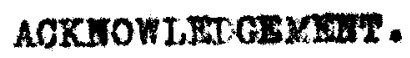

I now take this opportunity to exprees ay gratituãe to DF. W. Fanilton for his invaluable drection and enoouragement throughout this worky to extend ay thanks to Dr.C.B1ra of the Department of Surfery for his agletenoe and pugest10ns; and to offer my appreciation to Dr. S. D.Johnson and Mr. E. Seeree of the Loulavil1e C1ty Hopptal for asalstanos and instruotion in $x$-ray photography.

John H. Rompl 